\title{
Effect of Garlic Supplementation on the Growth Performance and Body Condition Score in Murrah Buffalo Calves
}

\author{
Mohan Vamsi Duvvu*, K. Ananda Rao, Ch. Venkata Seshaiah and D. Srinivas Kumar \\ Department of Livestock Production Management, N.T.R. College of Veterinary Science, \\ Gannavaram, Krishna district, Andhra Pradesh, India \\ *Corresponding author
}

\section{A B S T R A C T}

\section{Keywords}

Garlic supplementation,

Murrah buffalo calves,

Growth performance,

Body condition score,

Body weight gain

Article Info

Accepted:

26 January 2018

Available Online:

10 February 2018
An experiment was conducted to study the effect of varying levels of garlic supplementation on growth performance and body condition score in Murrah buffalo calves. In a CRD model, 18 Murrah buffalo calves in the age group of 4-5 months were randomly divided into three groups $\left(\mathrm{T}_{0}, \mathrm{~T}_{1}\right.$ and $\left.\mathrm{T}_{2}\right)$ with six calves in each group. The $\mathrm{T}_{0}$ group served as the control whereas the $\mathrm{T}_{1}$ and $\mathrm{T}_{2}$ groups were supplemented with garlic powder at the dose rate of 250 and $300 \mathrm{mg}$ per $\mathrm{kg}$ body weight, respectively for a period of 90 days. The results of the experiment revealed a significant $(\mathrm{P}<0.01)$ improvement in the overall feed intake, body weight gain, average daily gain, body condition score and feed conversion efficiency in garlic supplemented buffalo calves $\left(\mathrm{T}_{1}\right.$ and $\left.\mathrm{T}_{2}\right)$ compared with the control group $\left(\mathrm{T}_{0}\right)$ while, the difference between $\mathrm{T}_{1}$ and $\mathrm{T}_{2}$ groups was not significant. Thus, dietary supplementation of dried garlic either at 250 and $300 \mathrm{mg}$ per $\mathrm{kg}$ body weight improves growth performance in calves.

\section{Introduction}

Calves are the future replacement stock of the herd. But, nowadays the dairy farming is at stake because of heavy losses incurred due to the death of calves which is mainly due to calf scours and other calfhood diseases. These diseases are due to the poor immune status of the calves and this weak immunological profile predisposes them to various diseases and conditions that affect their survivability.

With the ban on the use of antibiotics as feed additives and growth promoters in animal nutrition, livestock scientists are now shifting their attention towards natural and safe products like organic acids, probiotics and herbal growth promoters (Jayasena and Jo, 2013). Herbs are known to have health benefits on animals when used as feed additives. Most of the herbal feed additives belong to the class of isoprene derivatives, flavonoides and glucosinolates which act as natural antibiotics or anti-oxidants (Rhodes, 1996 or Hirasa and Takemasa, 1998).

The beneficial effects of herbs in farm animals may arise from the activation of feed intake, immune stimulation, antibacterial, coccidiostatic, anthelmintic, antiviral, antiinflammatory activity and antioxidant properties. Herbs also contribute to the 
nutrient requirements of the animals, stimulate the endocrine system and intermediate nutrient metabolism (Wenk, 2003).

Garlic (Allium sativum) has been a subject of considerable interest as a medicinal and therapeutic agent globally since ancient times. In ancient times, garlic was taken as remedy for intestinal disorders, flatulence, worms, respiratory infections, skin diseases, wounds, symptoms of ageing and many other ailments. The main pharmacological effects of garlic are attributed to its organosulphur compounds (Tapieroa et al., 2004). In vitro studies have shown that garlic possesses antibacterial, antifungal, antiparasitic, antiviral (Ankri and Mirelman, 1999), antioxidant (Prasad et al., 1995), as well as antithrombotic, vasodilatory and anticancer (Agarwal, 1996) activities. Garlic ingestion also enhanced the activity of phagocytosis and an increase in natural killer cell activity which promoted the immune system function and strengthened the body's defence mechanism (El-Shenawy and Hassan, 2008). Therefore, the present experiment was carried to find out the effect of varying levels of dietary supplementation of garlic powder on the growth performance and body condition score in Murrah buffalo calves.

\section{Materials and Methods}

\section{Experimental location}

The present experiment was carried out at Buffalo Research Station, Venkataramannagudem, West Godavari, Andhra Pradesh. This research station is located at $16.49^{\prime} \mathrm{N}$ latitude and $81.30^{\prime} \mathrm{E}$ and 18 metres above the mean sea level.

\section{Experimental animals and experimental design}

The present study was carried out on 18 Murrah buffalo calves of 4-5 months age, which were randomly allotted into 3 groups $\left(\mathrm{T}_{0}, \mathrm{~T}_{1}\right.$ and $\left.\mathrm{T}_{2}\right)$ of 6 animals in each group based on their body weight and sex in Completely Randomized Design. The calves in the $\mathrm{T}_{0}$ group served as control and the calves in the $T_{1}$ and $T_{2}$ group were supplemented with garlic powder at the dose rate of 250 and $300 \mathrm{mg}$ per $\mathrm{kg}$ body weight, respectively in their concentrate feed. The experiment was conducted for a period of 90 days.

\section{Housing and feeding management}

All the experimental calves were housed individually in a well-ventilated shed with a provision for individual feeding and water facilities. The calves were fed with chopped green fodder (Hybrid Napier) and concentrate mixture (calf grower) as the basal diet as per their body requirements.

\section{Preparation of garlic powder}

Garlic bulbs were purchased from the local market and were dried under the shade for a period of 15 days. After drying, the outer husks were removed and the bulbs were ground to fine powder by using electrical mixer.

\section{Health management}

All the experimental calves were dewormed 10 days prior to the beginning of the experiment with Fenbendazole at the dose rate of $10 \mathrm{mg}$ per $\mathrm{kg}$ body weight and were vaccinated with Foot and Mouth disease vaccine during the second month of the experimental trial.

\section{Parameters studied}

The feed intake was calculated on dry matter basis. The total quantity of feed offered to each calf was recorded and the quantity of feed left over after 24 hours was weighed and 
the difference was calculated to know the average daily feed intake of the calves. The body weight of all the experimental calves was recorded at fortnightly intervals using a platform weighing balance. The average daily gain was calculated by subtracting the initial body weight from the final body weight and dividing it by the number of days. The body condition score was assessed by using the BCS scale developed by Alapati et al., (2010) based on the amount of fat reserves at 8 skeletal check points by vision and palpation on a 1 to 5 scale. The feed conversion efficiency was calculated using the formula (Banerjee, 1998).

\section{Analysis of data}

The data was analysed for significant differences among the groups for growth parameters and body condition score using ANOVA and Post-hoc tests as implemented in SPSS version 16.0 (SPSS, 2008).

\section{Results and Discussion}

The results of the current study revealed significant $(\mathrm{P}<0.01)$ improvement in feed intake in buffalo calves supplemented with garlic compared with control group of calves (Table 1). This might be attributed to sulphur containing compounds in garlic, such as allicin, which secretes digestive enzymes, stimulates appetite and balances intestinal bacterial flora which leads to increase feed intake and improved digestion (Khalil et al., 2001).

Similar results of increased feed intake was reported by Ghosh et al., (2010) in crossbred calves, Kleczkowski et al., (2004) and Krusinski (2004) in piglets, Javandel et al., (2008) in broilers and El-ghamry (2004) in ducks. Contrary to the present findings, depressed feed intake due to garlic powder supplementation was reported by Holden et al., (1998) and Cullen et al., (2005) in weaning pigs and no effect on growth performance was observed by Bampidis et al., (2005) in grazing lambs and Chen et al., (2008) in growing pigs.

Similar to the feed intake, significant $(\mathrm{P}<0.01)$ improvement in the overall body weight gain in the garlic supplemented calves over the control group was observed (Table 2). The improvement in feed intake and utilization in garlic supplemented calves might also increased the body weight gain in calves. These results were further supported by the findings of Ghosh et al., (2010) and Balamurugan et al., (2014) in crossbred calves and Badias and Yaniz (2004) in lambs. However, depressed growth rate in weaner pigs and broiler birds was observed by Holden et al., (1998) and Javandel et al., (2008), respectively, due to decreased feed intake.

The average daily gain (grams) in body weight of experimental buffalo calves is presented in Table 3 and the difference in daily gain was significant $\quad(\mathrm{P}<0.01)$ in buffalo calves supplemented with garlic powder when compared with the control group.

This improvement in the average daily gain might be due to the action of compounds like allicin and oregano-sulfur (Pourali et al., 2010). Ahmed et al., (2009) reported that addition of $2.5 \%$ natural juice containing garlic significantly $(\mathrm{P}<0.05)$ increased the average daily gain in growing buffalo calves as compared with the control group.

A higher average daily gain was also noted by Yan et al., (2011) in pigs on supplementing with fermented garlic powder at the dose rate of 2 grams per $\mathrm{kg}$ of concentrate. However, garlic supplementation resulted in no positive influence on the average daily gain in growing lambs and broiler chicks (Bampidis et al., 2005 and Javandel et al., 2008). 
Table.1 The Mean \pm SE and analysis of variance of daily feed intake (DM) of murrah buffalo calves supplemented with different levels of garlic in the diet

\begin{tabular}{|l|c|c|c|}
\hline Time Interval & $\mathrm{T}_{0}$ group (in kg) & $\mathrm{T}_{1}$ group (in $\mathrm{kg}$ ) & $\mathrm{T}_{2}$ group (in $\mathrm{kg}$ ) \\
\hline $\mathbf{0 - 1 5 ^ { \text { th } }}$ day & $2.25 \pm 0.16$ & $2.25 \pm 0.14$ & $2.26 \pm 0.12$ \\
\hline $\mathbf{7 5 - 9 0 ^ { \text { th } }}$ day ** & $3.02 \pm 0.15^{\mathrm{a}}$ & $3.09 \pm 0.13^{\mathrm{b}}$ & $3.12 \pm 0.18^{\mathrm{b}}$ \\
\hline Overall DM intake ** & $239.07 \pm 0.56^{\mathrm{a}}$ & $242.00 \pm 0.38^{\mathrm{b}}$ & $242.47 \pm 0.24^{\mathrm{b}}$ \\
\hline
\end{tabular}

Means with similar superscript doesn't differ significantly; ** indicate $\mathrm{P}$ value $<0.01$

Table.2 The Mean \pm SE and analysis of variance of body weight gain of murrah buffalo calves supplemented with different levels of garlic in the diet

\begin{tabular}{|l|c|c|c|}
\hline Time Interval & $\mathrm{T}_{0}$ group (in kg) & $\mathrm{T}_{1}$ group (in $\mathrm{kg}$ ) & $\mathrm{T}_{2}$ group (in kg) \\
\hline $0^{\text {th }}$ day & $81.50 \pm 1.26$ & $81.17 \pm 0.95$ & $81.83 \pm 1.17$ \\
\hline $9^{\text {th }}$ day ** & $125.30 \pm 1.04^{\mathrm{a}}$ & $129.12 \pm 0.67^{\mathrm{b}}$ & $130.48 \pm 1.05^{\mathrm{b}}$ \\
\hline Overall weight gain** & $43.8 \pm 0.38^{\mathrm{a}}$ & $47.95 \pm 0.49^{\mathrm{b}}$ & $48.65 \pm 0.24^{\mathrm{b}}$ \\
\hline
\end{tabular}

Means with similar superscript doesn't differ significantly; ** indicate $\mathrm{P}$ value $<0.01$

Table.3 The Mean \pm SE and analysis of variance of average daily gain of murrah buffalo calves supplemented with different levels of garlic in the diet

\begin{tabular}{|l|c|c|c|}
\hline Time Interval & $\mathrm{T}_{0}$ group (in grams) & $\mathrm{T}_{1}$ group (in grams) & $\mathrm{T}_{2}$ group (in grams) \\
\hline $\mathbf{0}-\mathbf{1 5}^{\text {th }}$ day $* *$ & $383.33 \pm 7.60^{\mathrm{a}}$ & $446.67 \pm 6.15^{\mathrm{b}}$ & $450.00 \pm 5.77^{\mathrm{b}}$ \\
\hline $\mathbf{7 5 - 9 0 ^ { \text { th } }}$ day $* *$ & $562.50 \pm 5.28^{\mathrm{a}}$ & $616.67 \pm 7.60^{\mathrm{b}}$ & $621.67 \pm 3.57^{\mathrm{b}}$ \\
\hline $\begin{array}{l}\text { Overall average } \\
\text { daily gain } * *\end{array}$ & $486.66 \pm 4.22^{\mathrm{a}}$ & $532.78 \pm 5.40^{\mathrm{b}}$ & $540.55 \pm 2.64^{\mathrm{b}}$ \\
\hline
\end{tabular}

Means with similar superscript doesn't differ significantly; ** indicate $\mathrm{P}$ value $<0.01$

Table.4 The Mean \pm SE and analysis of variance of feed conversion efficiency of murrah buffalo calves supplemented with different levels of garlic in the diet

\begin{tabular}{|l|c|c|c|}
\hline Time Interval & $T_{0}$ group & $\mathrm{T}_{1}$ group & $\mathrm{T}_{2}$ group \\
\hline $\mathbf{0 - 1 5 ^ { \text { th } }}$ day** & $0.39 \pm 0.11^{\mathrm{a}}$ & $0.34 \pm 0.13^{\mathrm{b}}$ & $0.34 \pm 0.08^{\mathrm{b}}$ \\
\hline $\mathbf{7 5 - 9 0 ^ { \text { th } }}$ day *** & $0.36 \pm 0.11^{\mathrm{a}}$ & $0.33 \pm 0.09^{\mathrm{b}}$ & $0.33 \pm 0.11^{\mathrm{b}}$ \\
\hline
\end{tabular}

Means with similar superscript doesn't differ significantly; ** indicate $\mathrm{P}$ value $<0.01$

Table.5 The Mean \pm SE and analysis of variance of body condition score of murrah buffalo calves supplemented with different levels of garlic in the diet

\begin{tabular}{|l|c|c|c|}
\hline Time Interval & To group & $\mathrm{T}_{1}$ group & $\mathrm{T}_{2}$ group \\
\hline $0^{\text {th }}$ day & $2.00 \pm 0.17$ & $2.08 \pm 0.08$ & $0.34 \pm 0.08$ \\
\hline $90^{\text {th }}$ day $* *$ & $2.67 \pm 0.17^{\mathrm{a}}$ & $3.17 \pm 0.11^{\mathrm{b}}$ & $3.17 \pm 0.23^{\mathrm{b}}$ \\
\hline
\end{tabular}

Means with similar superscript doesn't differ significantly

$* *$ indicate $\mathrm{P}$ value $<0.01$ 
Similar to the trend of growth rates, significant $(\mathrm{P}<0.01)$ improvement in the feed conversion efficiency was also observed in calves supplemented with garlic compared to the control group (Table 4). This could be attributed to allicinin garlic which promotes the performance of the intestinal flora thereby enhancing digestion and improved growth rates (Pourali et al., 2010). Garlic significantly enhances the villus and globlet cell numbers in the duodenum, jejunum and ileum of birds (Tatara et al., 2005) which might enhance feed conversion efficiency in calves. However, no positive influence on the feed conversion efficiency by garlic supplementation was reported by Bampidis et al., (2005) in growing lambs and Balamurugan et al., (2014) in crossbred calves.

The overall BCS in all the Murrah buffalo claves was improved due to increase in body weight (Table 5). However, significant improvement $(\mathrm{P}<0.05)$ in $\mathrm{BCS}$ was observed in garlic supplemented groups over the control group, while the BCS was not different between the two garlic supplemented groups.

Based on the present results, it can be concluded that dietary supplementation of garlic powder either at the dose rate of 250 or $300 \mathrm{mg}$ per $\mathrm{kg}$ body weight has a significant impact on the growth performance in the murrah buffalo calves.

\section{References}

Agarwal, K. C., 1996. Therapeutic actions of garlic constituents. Medicinal research reviews. 16: 111-124.

Ahmed, A. A., Bassuony, N. I., El-Habiab, S. A., Awad, S., Aiad, A. M. and Mohamed, S. A. 2009. Adding Natural Juice of Vegetables and Fruitage to Ruminant Diets Nutrients Utilization, Microbial Safety and Immunity, Effect of Diets Supplemented with Lemon,
Onion and Garlic Juice Fed to Growing Buffalo Calves. World Journal of Agricultural Sciences. 5: 456-465.

Alapati, A., Kapa, S. R., Jeepalyam, S., Rangappa, S. M. P. and Yemireddy, K. R. 2010. Development of the body condition score system in Murrah buffaloes: validation through ultrasonic assessment of body fat reserves. Journal of veterinaryscience. 11: 18.

Ankri, S. and Mirelman, D. 1999. Antimicrobial properties of allicin from garlic. Microbesand infection. 1: 125-129.

Badias, G. and Yaniz, J. 2004. Effect of addition of aromatic plants in feed for lambs on daily weight gain and production index. Georgica 10: 11 .

Balamurugan, N., Sundaram, S. M., Sivakumar, T. and Rajkumar, J. S. I. 2014. Effect of Garlic (Allium sativum) Supplementation on the Growth Performance of Crossbred Calves. Animal Production. 16: 78-87.

Bampidis, V. A., Christodoulou, V., Christaki, E., Florou-Paneri, P. and Spais, A. B. 2005. Effect of dietary garlic bulb and garlic husk supplementation on performance and carcass characteristics of growing lambs. Animal feed science and technology. 121: 273 - 283.

Banerjee, G. C. 1998. A textbook of animal husbandry, Eighth edition, Oxford and IBH publishing Co. Pvt. Ltd, New Delhi: 778.

Chen, Y. J., Kim, I. H., Cho, J. H., Yoo, J. S., Wang, Q., Wang, Y. and Huang, Y. 2008. Evaluation of dietary L - carnitine or garlic powder on growth performance, dry matter and nitrogen digestibilities, blood profiles and meat quality in finishing pigs. Animal Feed Science and Technology. 141: 141-152.

Cullen, S. P., Monahan, F. J., Callan, J. J. and O'doherty, J. V. 2005. The effect of dietary garlic and rosemary on grower-finisher pig performance and sensory characteristics of pork. Irish Journal of Agricultural and Food Research. 44: 57-67.

El-Ghamry, A. A. 2004. Effect of some medicinal plants and live yeast as feed additives on the productive performance of Muscovy ducks. Egyptian Poultry Science Journal. 24: 639653.

El-Shenawy, S. M. and Hassan, N. S. 2008. Comparative evaluation of the protective 
effect of selenium and garlic against liver and kidney damage induced by mercury chloride in the rats. Pharmacological Reports. 60: 199.

Ghosh, S., Mehla, R. K., Sirohi, S. K. and Roy, B. 2010. The effect of dietary garlic supplementation on body weight gain, feed intake, feed conversion efficiency, faecal score, faecal coliform count and feeding cost in crossbred dairy calves. Tropical Animal Health and Production. 42: 961-968.

Hirasa, K. and Takemasa, M. 1998. Spice science and technology. CRC Press.

Holden, P.J., Mckean, J. and Brandenburg, E. 1998.Biotechnicals for pigs-Garlic (ASLR1559). In ISU Swine Research Report. Iowa State University, Ames.

Javandel, F., Navidshad, B., Seifdavati, J., Pourrahimi, G. H. and Baniyaghoub, S. 2008. The favourite dosage of garlic meal as a feed additive in broiler chickens rations. Pakistan Journal of Biological Sciences. 11: 17461749.

Jayasena, D. D. and Jo, C. 2013. Essential oils as potential antimicrobial agents in meat and meat products: A review. Trends in Food Science \& Technology. 34: 96-108.

Khalil, R. H., Nadia, B. M., Soliman, M. K. 2001. Effects of Biogen and Levamisole $\mathrm{Hcl}$ on the immune response of cultured Oreochromisniloticus to Aeromonas hydrophila vaccine. Beni-suef Vet. Med. Journal. 11: 381-392.

Kleczkowski, M., Kasztelan, R., Jakubczak, A., Klucinski,W., Sitarska, E. and Cetnarowicz, A.2004. Garlic as a biostimulator and antibiotic in the raising of piglets. Medycyna Weterynaryjna. 60: 384-387.

Krusinski, R. 2004. Herb addition level in feed mixture for fattening pigs. Annales Universitatis Mariae Curie SkodowskaSectio EE Zootechnica.22: 123-127.

Pourali, M., Mirghelenj, S. A. and Kermanshahi, H.2010. Effect of garlic powder on productive performance and immune response of broiler chickens challenged with Newcastle disease virus. Global Veterineria. 4.

Prasad. K., Laxdal, V. A., Yu, M. and Raney, B. L. 1995. Antioxidant activity of allicin, an active principle in garlic. Molecular and Cellular Biochemistry. 148: 183-189.

Rhodes, M. J. C. 1996. Physiologically-active compounds in plant foods: An Overview. Proceedings of the Nutrition Society. 55: 371384.

SPSS 2008 Statistical Packages for the social science, Release 16, SPSS INC, Chicago, USA.

Tapieroa, H., Townsend, D. M., and Tew, K. D. 2004. Organosulfur compounds from alliaceae in the prevention of human pathologies. Biomedicine \& Pharmaco therapy. 58:183-193.

Tatara, M. R., Sliwa, E., Dudek, K., Mosiewicz, J., and Studzinski, T. 2005. Effect of aged garlic extract and allicin administration to sows during pregnancy and lactation on body weight gain and gastrointestinal tract development of piglets: Morphological properties of the small intestine. Part II Bulletin-Veterinary Institute in Pulawy. 49: 349.

Wenk, C. 2003. Herbs and botanicals as feed additives in monogastric animals. Asian Australasian Journal of Animal Sciences. 16: 282-289.

Yan, L., Meng, Q. W., Ao, X., Zhou, T. X., Yoo, J. S., Kim, H. J., and Kim, I. H. 2011. Effects of fermented garlic powder supplementation on growth performance, blood characteristics and meat quality in finishing pigs fed lownutrient-density diets. Livestock Science. 137: 255-259.

\section{How to cite this article:}

Mohan Vamsi Duvvu, K. Ananda Rao, Ch. Venkata Seshaiah and Srinivas Kumar, D. 2018. Effect of Garlic Supplementation on the Growth Performance and Body Condition Score in Murrah Buffalo Calves. Int.J.Curr.Microbiol.App.Sci. 7(02): 2972-2977.

doi: https://doi.org/10.20546/ijcmas.2018.702.361 